\title{
Western Works and Views On Hadith: Beginnings, Nature, and Impact
}

\section{Dr. Mohammed Salem ALSHEHRI*}

\begin{abstract}
Batı'da Hadis Üzerine Yapılan Çalışmalar ve Temel Yaklaşımlar
Öz: Oryantalist hadis çalışmalarının ortaya çıkış tarihini inceleyen bu makale, Batılı araştırmacıların hadis hakkındaki görüşlerini ve başlıca eserlerini, ayrıca bunların Müslüman dünyadaki etkilerini ele almaktadır. Hadisleilgiliçalışmalarınbaşlangıcı 1890-1950 dönemineuzanır.lgnazGoldziherile Josef Schacht'ın kurucu eserleri bu dönemde yazılmış, her iki yazarın görüşleri Batı́nın hadis, siyer ve ilk dönem İslam tarihine bakışını büyük ölçüde şekillendirmiştir.
\end{abstract}

Anahtar Kelimeler: Hadis, Oryantalistler, Goldziher, Schacht, isnad, metin, Kur'ancılar.

\begin{abstract}
This is a brief history of the beginning of the Orientalist studies of hadith, which will shed light on the most prominent works and views Western scholars on hadith, the nature as well as the impact of their outcomes on Muslims and Western worlds. The beginning era of such studies was between 1890 to 1950. In this period, two influential and founding works of Ignatz Goldziher and Josef Schacht emerged, and both have immensely contributed in shaping the Western perspective regarding hadith, the Prophetic Biography and early history of Islam.
\end{abstract}

Keywords: Hadith, Orientalists (Western scholars), Goldziher, Schacht, isnad, matn, Quranists.

This is a brief historical glance at the major scholarly views on hadith literature by the early Orientalists who laid down the foundations of the Western studies of Hadith, and the history of early Islam. Unlike hadith studies, any researcher tracing the history of the Western scholarship of the Qur'ân and its developments over time, finds no difficulty in locating many works available in English conducted for this purpose. Literature on the history of the Western studies of hadith, on the other hand, is difficult to find autonomously, and can only be donethroughnavigating a considerablenumber ofWestern writings and collecting information on the subject and piecing them together.This chapter, therefore, is an attempt to fill this gap and demonstrate a concise chronology of modernWesterninterestinhadithwhilehighlightingitsbeginningandthephasesitwent through. It is difficult to discuss, even briefly in this limited space, all studies conducted related to hadith in this period. Nevertheless, the focus will be placed on the most prominent works written in this period, which will be down to two main influential studies, as will be seen later in this paper, with showing the justification for choosing them. One of the main objectives of this paper is to give readers an insight into the outcomes of early

* Department of Al-Sunnah and its Disciplines, College of Sharee'ah and Principles of Religion, King Khalid University, Saudi Arabia. 
Western investigations, and to briefly bring to the reader's attention the impact of early Orientalist scholarship of hadith in both academic worlds; Muslim and Western.

1. Modern Academic Writings of Western scholars on hadith: Beginnings and Nature

Modern Western interest in hadith began towards the mid-19th century. The central theme of this interest was to study the formative period of Islam. Although the scholarly approach towards hadith did not actually start until the 19th century, a growing interest in the transmissions and collections of hadith had been noticed since the late 17th century. However, probing hadith literature to determine the historical origins of Islam, unlike the Qur'ân, did not seem to be a priority for Orientalists in their 17th and 18th century academic studies. The reason for that could be associated with two general facts: First, the negative attitude towards Islam and its Prophet had been dominant in Europe since medieval timesand hadinfluenced someleading Orientalists, among them wastheFrench philosopher, Barthelemy_d'Herbelot (1625-1695), who was the first to offer some critical observations on hadith literature in his encyclopaedic work 'Bibliotheque Orientale'. Besides his scepticalviews on all thePropheticTraditions, hesometimes depicts Muhammadasa'false Prophet'. This attitude might have led to an impression that the Prophetic Traditions were of no value in terms of historical exploration. Second, it could be due to several views held bysomeinfluentialhistorianssuchasErnestRenan(1823-1892)whosuggested thathadith deserve less attention than the Qur'ân, because it was less historical.

Both factors could have possibly contributed to slowing down intellectual zeal for studying hadith in a more vigorous and academic mannerformore than a century until the Western study of hadith was taken up again after these observations.

\subsection{Beginnings}

The first modern studies on the subject of hadith were stimulated by the growing interest of Western scholars in the life events of Muhammad that are found in his Traditions, which opened their eyes to the importance of the Prophetic Traditions besides the Qur'ân. This led them to critiquing the reliability of these events as well as investigating the legal institutions of Islamic history. They laid their approach on the basis of the origin and development of Islam and its characteristic features. Therefore, early critical remarks on hadith can be traced back to the writings of historians who were concerned with the reconstruction of the biography of Muhammad, suchas; Gustav Weil (1808-1889) and Aloys Sprenger (1813-1856). After careful investigation of other Islamic sources, William Muir (1819-1905) in his The life of Mahomet considered hadith, alongside the Qur'ân, the chief material for the biography of Muhammad. He also sought to lay down some criteria in order to identify reliable Traditions to be used 
Western Works and Views On Hadith: Begınnıngs, Nature, and Impact

for this purpose.Theseearly remarks and discussions managed to draw theattention of a wider readership in theWest to the subjects of hadith, which are considered to be the gateways to more well-structured scholarly works that came later.

Other than historians, the significance of the Traditions as a subject of scholarly research was also realised by another group of Orientalists. In the 1870s, specialists in Islamic law became aware of the position of hadith in Islam when they attempted to answer the question of the origins of Islamic law and its development. It was understood that the hadith were a prime legal source for Islamic law after the Qur'ân. Eduard Sachau, a German Orientalist, (1845-1930) was probably one of the first in the $19^{\text {th }}$ century to identify the strongrelationbetweenhadithandlslamiclawbyrecognisingitssignificance,alongsidethe Qur'ân, in forming the basis from where sharîa'ah derives its values and ordinances. In order toadequatelyshowtheprogress which Orientaliststudies of hadith started, itis useful here to divide this historical period into two main phases. These two phases are:

\section{a) Preliminary Remarks}

This phase extends from 1840 to 1889 . hadith during this phase, as seen earlier, was not discussed on a full-scale level. It was dealt with within the Orientalists'broad discussions of the early history of Islam together with the sirah (biography of Muhammad) and the Islamic legal system. Interest in locating reliable historical materials for the origins of Islam and the life of Muhammad led Orientalists to look into the Islamic Traditions in order to evaluate them and hence, determine whether or not they can beconsideredasa valid textual source. The remarks of some scholars of this phase, such as Weil, Reinhart Dozy (1820-1883), Sprenger, and Muir, weregenerallydubiousabout the genuineness of hadith literature, though they varied in one way or another in terms of their scepticism.

b) Independent Studies

Sincethe 1890sand untilthe present, hadith studies have been anentirelyindependent discipline in the Western scholarship of Islam, which has become more scholarly and has gained more maturity than in the past. For a better understanding of this historical phase, it would be appropriate to divide it into two major historical periods:

The first began in 1890 until 1950 with the publishing of major studies that led to the foundations of modern Western attitudes towards hadith. This new epoch beganwiththepublication ofMuhammedanischeStudien(MuslimStudies), theprominent work of Ignaz Goldziher. It ended with The Origins of Muhammadan Jurisprudence by JosephSchachtin 1950. Both magnumopuses by thetwoauthors, as will beelaborated later, arestill regarded as the mostauthoritativestudies on the subjectuntil the present time. Ever since that time, the comprehensive study of hadith evolved as an independent subject inWestern academia when almost all aspects of hadith were subjected to 
intensive study by specialists who attempt to achieve a better understanding of the early stage of Islam. Although one must focus on the works written during this period, the works prior to this era cannot be completely ignored.The second period starts from 1950 until the present time, which began with the works of James Robson.

The reason for dividing this stage into two periods is that each of them has its own distinctive characteristics in relation to the progress of hadith studies in the West, on the one hand, and Western thought of hadith, on the other.

For limitation purposes, this chapter is concerned with the first period (1890-1950) aiming to give an introductory historical account of early modern views regarding hadith. This is because knowing these views gives one the chance to trace the main developments and major changes in the line of Orientalist thoughts on the subject.

\subsection{Nature:}

As noted earlier, Muslim Traditions initially became a subject of study for those searching foranysecondary historical records aftertheQur'ânthatcould helpthem, alongside sîrah books, in their project of forming a critical biography of the life of Muhammad, as well as the history of the early Muslim community. Western historians when studying early Islam use any available sources in this field, and apply different historical-analytical methodstoattain possiblecertainty byexamining such sourcestoseeifwhatisalleged to have happened, actually did happen. Their first goal is to present a corpus of fact in order to answer the questions;' what really happened, and why?'For this reason, the Traditions needed to beexamined to determinetheir possible utility as a trustworthy sourcefor this academic project. So, they were mainly studied from a historical perspective which brought their attention to hadith literature in the first place. Based on that, it is clear that the chief objective ofWestern research on hadith was set to explore and describe the origin, growth, and development of hadith literature in an attempt to verify its authenticity.

This interest in the historicity of hadith is still behind most of the works on the subject to date, which have undoubtedly become very valuable to hadith studies and indeed to other disciplines of Islamic studies. This Orientalist endeavour was immense and much appreciated by the scholarly community whoworknotonlyon hadith buton other Islamic subjects as well. The method that they employ is historical criticism. For the historical critic, if a hadîthcannot be shown coming from the Prophet, then at least it will prove to be interesting as a source of thought, theories and developments that took place after the death of the Prophet.

Historical criticism is an art to distinguish the truth from the false concerning the facts of the past. As soon as a historical critic puts his hands on a work from the past, immediately questionsrelatingtoitsauthenticity, integrity, meaningandauthorityareraised.Forexample, 
does the work really come from the time it claims to come from or is it a later work? These can be solved by using the auxiliary sciences of history such as paleography, orthography, diplomatics,andalsobylookingatintrinsicevidencesuchasanachronisms.Broadlyspeaking, mostofWesternscholarsassessedthehadithmaterialsashistorical sources, astheyneedtobe assured about their reliability in order to establish which historical period they reflect.

\subsection{Major Works and Views of Early Orientalists on hadith from 1890 to 1950:}

Of the manyacademic works published throughout this period concerning hadith, only two major works are worthy of consideration. The first is Ignaz Goldziher's MuhammedanischeStudien(MuslimStudies)whichcoincidedwiththebeginning ofthisera. Interestingly, the era also ended with the publication of a second important work; that is,JosephSchacht'sTheOrigins of Muhammadan Jurisprudence.Thediscussion of early Western views in this section will revolve around these two works. This choice can be justified for the following reasons:

First, many Western writings on the subject of hadith and other Islamic subjects are largely dependent upon the results of both studies. This is due to the fact that theconclusions of Goldziher and Schacht constitute"... a point of departure for almost all other studies on hadith in the West." Second, they are still considered as main references on Islam in the West by students and specialists in Islamic studies, so it is hard to find any modern research on hadith whichescapes referencetothesetwoauthors.Third,themostimportantWestern encyclopaedias suchas'Encyclopaedia of Islam'and'EncyclopaediaBritannica',adopttheir conclusionswith regard totwo entries;' hadith'and'Sunnah'Fourth, theviews embraced in both works are still dominant in the West, and only a few scholars have scientifically challenged some of them, such as G.H.A Juynboll, H. Motzki, and Mustafa Azami. Fifth, other

Orientalist researches on the subject in this period have not brought about substantive changes in the line of Western thought regarding hadith studies.

For these reasons, the key arguments related to hadith and its history found in the works of Goldziher and Schacht will be highlighted here as representative of the Western views on hadith up to the second half of the twentieth century. By sketching out both studies, the reader, it is hoped, will gain a historical background of the leading works and observations made on the subject in its early stages.

\subsection{Outline of the Views of Goldziher and Schacht}

\subsubsection{Ignaz Goldziher's Views}

At the end of the $19^{\text {th }}$ century, Ignaz Goldziher published his renowned two-volume book entitled 'Muhammedanische Studien' in 1889 and 1890, which was later trans- 
lated into English by C. R. Barber and S. M. Stern under the title 'Muslim Studies'. Afteritspublication,thebookwasacclaimedasamasterpieceandregardedas"... nineteenthcentury Europe's great breakthrough in Islamic studies". The second volume was devoted entirely to the subject of hadith. This was a pioneering academic work that determined the course of the study of hadith in theWestern scholarship of Islam ever since. Goldziher's book formed thevery basisforfurther research in the field where manylater scholars, such as Henri Lammens (1862-1937), and David Samuel Margoliouth (1858-1940), established their studiesonitsfindings, therebyextendinghisideas.Importantly,Goldziherattemptedinthesecond volume to give a complete image of the history of hadith during the early period of Islam.

He discusses, in an all-embracing approach, the origins and development of hadith by focusing on its status during the era of the Umayyad and Abbasid Caliphates as well as its relation to partisan and theological conflicts. Then, he analyses the reaction of traditioniststowardsincidentsofforgeryinhadith, and dedicatestwochapterstowards the end of his study to discussing the issue of recording hadith. Applying a critical and historical-analytical approach, Goldziher, in MS, introduces the story of hadith, its origins and evolution in a version which seems to be completely, in almost all aspects, different from the one that is agreed-upon in Muslim classic sources. In the preface, he states that thereis noscientificguaranteethat supports the notion believed by Muslims that the amount of Traditions attributed to the Prophet that are found in classic hadith compilations reflect his real words, deeds and some aspects of the early life of the first Muslim generations. Instead, he thinks this bulk of hadith were in fact the result of the social and religious growth that occurred in the early Muslim community. He claims:

The hadith will not serve as a document for the history of the infancy of Islam, but rather as a reflection of the tendencies which appeared in the community during the mature stages of its development. It contains invaluable evidence for the evolution of Islam during the years when it was forming itself into an organised whole from powerful mutually opposed forces.

This quotation clearly indicates Goldziher's unique contribution to the gradual evolution of Islam. He reached this general conclusion after several reflections and observationswhilestudying hadithliterature,especiallythoseconcerningtheamount of Prophetic narrations. He realised that in early times they were less in number than those recorded in later eras. For example, what was narrated through theyoung Companions was, by and large, more than those which were recounted by the senior Companions who are supposed to have known more about the Prophet and his Sunnah. Also, it was found that the number of hadith in later works is much more than what was documented in the earlier ones. This indicates to him, that a large proportion originated after the time of the Prophet and his Companions. This suggests to Goldziher that an early large-scale fabrication of hadith took place. At this point, 
Goldziher differed in his interest of studying hadith from his predecessors, especially the biographers of the Prophets'life who sought to extract actual historical information from the Traditions to aid them in their task. Instead, he was interested in the forged Traditions which reflect the problems of the post-Prophetic era.

Bythis book,Goldziherbecame, infact, the firstWestern critic who systematically questioned the historicity and authenticity of the entire contents of hadith. One of the overall goals of MS was to study the development of hadith and assess the role it played in the historical developmentof Islam. Heunderstands hadith literatureasa repositoryholding only a few narrations about the real life and teachings of Muhammad. Instead, it is seen as a rich sourceofhistorical facts and evidencewhich reveal thetransformational stages in thelegal and religious thought of the Muslim society which occurred in its early time.

Throughouttheentirework, Goldziherbuilds hisstudyonanalysingand examining the contents of hadith texts, and he never considers probing the chains of authorities attached to them as a useful tool in determining the dating or the reliability of hadith. This is justified by his notion that investigating any isnâd must depend on the traditionist critical works of the narrators and their verdicts. This, to him, is problematic becausetherewasnoscientificgroundandrigorousstandardswhichallhadithauthorities can be checked against, but rather their assessment and credibility were based on individual traditionist's"dhawq"(taste). By focusing only on the texts, he also attempts to explore them further by transcending the written text to detect the tendencies and thoughts of different groups, which were expressed and concealed in a form of hadith. His objective is to formulate a comprehensive image of the reality of life in the formative period as much as possible, and to discover how hadith developed over time and how it influences other branches of Islamic knowledge.

Nevertheless, Goldziher's methodology, regardless of its practical sophistication, has invited different critical responses from some specialists in the field. Johann Fueck, who is less sceptical about the authenticity of hadith, considers the methods used in Goldziher's study and other Orientalists influenced by him were to promote"...unlimited scepticism which opened the flood gates to caprice." This was, in Fueck's view, caused by the difficulty of finding admissible criteria to deal with the authenticity of hadith literature. Another scholar, Nabia Abbott, in her second volume of Studies of ArabicLiteraryPapyri,arguesagainstsomeofGoldziher'stheoriesrelatingtothehistory ofhadith.Shestatesthathadith passedthroughtheearlygenerationsofMuslimsinwritten form alongside the oral form of hadith. Based on that, hadith collections contain a large amount of authentic Traditions. She bases her argument on the fact that literacy was common in the Prophet's life among his people. 


\subsubsection{Goldziher and the Religious Evolution Theory}

The problematic features of Goldziher's analysis of hadith as illustrated by his critics as seen above, can be better understood if one pays sufficient attention to one of Goldziher's basic concepts regarding the nature of religion in general. This concept is rarely touched upon by critics, as a major factor in the intellectual mechanism of Goldziher's discussion with respect to the history of religion. With this in mind, it would be the key with which one can attempt to understand the basis of how Goldziher treats Muslim Traditions. From his early university studies, there were some Orientalists who greatly influenced the developmentofhisintellectualthoughtandresearchmethodologyinthearea of Arabicand Islamic studies. One of them was Alfred Von Kremer (1828-1889) whose works; Culturgeschichte DesOrientsUnterDenCahlifen(History oftheCultureoftheOrientunderCaliphs)andGeschichtederherrschendenldeendesIslam(HistoryoftheGoverningldeasoflslam)influenced Goldziher's universal view of religion and history to a great extent. After the departure of Kremer, Goldziher wrote a letter to his friend V. Rosen expressing his grief for his death mentioningKremer'sgreatimpactonhispersonalityandthoughtwhichconsiderablycontributed to the development of his approach and view regarding Islam.

Beside the emphasis on the relative independence of ideas, the most influential elements of Kremer's thought on Goldziher was his theory of religious evolution, i.e. the developmental process that comprehensively occurs in all historical aspects of religion. From this point, Goldziherstarted to believe passionately in this trend of ideas which later controlled his study of Judaism and Islam. Himself a Jew, Goldziher applied this theory of the evolving process, to the Old Testament to find out how the religious texts of the Torahevolved. For that purpose, he examined the historical origins of some Patriarchs'tales concluding that each tale was based on a myth, and the notion of each myth developed later "...either into religion or into history". This developmental process in the texts of the Torah was seen as an outcome of the psychological and imaginative practice of the Jewish mind expressed in various linguistic forms.

In the light of this theory, Goldziher perceives Islam as "...faith in constant evolution" whose basis was established rightfrom the beginning on borrowed materials from Judaism.In terms of hadith literature, he is not entirely convinced that the literature is without any grain of truth about the sayings and deeds of the Prophet. They possibly, he continues, contain some amount but it is very little and was later enhanced and developed by differentworldlyandreligious-mindedfunctionarieswhoproducedthelargestproportion of hadith materials. The reason for this textual evolution in hadith as explained in MS was to fulfillthelegal need of the growing Muslim society, which was surrounded by different social and political challenges when the Qur'ân did notspecificallymention these issues. Therefore, to Goldziher, Islamic law and dogma was not based, as believed by Muslims, on firm-divine principles and pure Prophetic communications. 
Western Works and Views On Hadith: Begınnıngs, Nature, and Impact

\subsubsection{Joseph Schacht's Work and Views:}

The appearance of Goldziher's work MS II in 1890 paved the way for a number of specialised writings on hadith literature and their origin, such as those of Snouck Hurgronje (1857-1936), Henri Lammens (1862-1937), and David Samuel Margoliouth (1858-1940). However, as stated earlier in the beginning of this research, in most of these writings theideas of Goldziherweretakenuporextended withoutmaking new premises that could take the arguments to a higher level of thought. In this period of time, there was one notable exception of the Orientalists, namely Johann Fueck (1894-1974), who criticisesthescepticalapproachofhispredecessors,arguingthathadithliteraturecontains manyauthenticTraditions.Goldziher'sattempttodatethehistoricaloriginsofhadithwas quite broad and at times rudimental. He never goes beyond his simple scepticism about theauthenticity of the bulk of hadith materials, and he limits his dating of hadith to general comments like'mature stages of its development' or 'first few centuries of Islam'. That was why Western scholars felt that there was a dominant need for a further step to "... discover a reliable method of positive hadith-criticism"in order to structurea"... practical theory for determining the chronology and provenance of any specific hadith".

According tothosescholars, thiswasaccomplished60yearslaterbyJosephSchacht in his influential studyentitled'TheOrigins of Muhammadan Jurisprudence'whichcarries four major themes. They are: the development of legal theory in early Islam, the growth oflegal hadith, thetransmission oflegaldoctrineintheUmayyadtimeandconflicts within the legal schools, and finally the development of technical legal thought. Schacht's work was highly appreciated by scholars in Western learned circles, especially those who were interested in the origin of Islamic law. J. N. D. Anderson in his review of Schacht's book states that Schacht was eagerly awaited by specialists in the field. In the same breath, H. Ritter concludes in his review of the same book, saying:

This thorough methodical and highly original book has considerably advanced our knowledge of the early development of one of the most important branches of the history of Islamic thought and has established a methodical base for investigations of this kind.

The whole thesis of Schacht was set to answer the question of the origin of Islamic legislation, and trace the development of the ancient legal schools of Muslims into what is currently known as'al-Madhahib al-Arba'ah', (Four Juristic Schools). The importance of his work was to know the original basis that Muslim law was mainly established upon in the first Islamic century. Historical and sociological approaches were applied in his study rather than theological and juristic. Islamicjurisprudence was viewed in Origins as historical phenomenon whose roots grew out of the context of social reality.

Heinvestigates the validity of the classicnotion that Islamicjurisprudencewasestablishedonfourmainelements:theQur'ân, hadith,ijma' (consensus), and qiyâs (analogical 
reasoning). The result of the investigation was that this traditional thought held by Muslims was not historically the initial structure of Muslim law;but rather a secondary stage product developed during the transmission of the legal system which began at the end of the first century. As a result, the Qur'ân and hadith were not believed to be the chief sources of sharîaah until the middle of the second century A.H.. In terms of the Qur'ân, Schacht suggests that the Qur'ân as a whole was not the prime foundation from the beginning; although, he acknowledges that some Qur'ânic rules related to family law, inheritance, cult and rituals were elements found in the Islamic legal structure from the beginning. Therefore, he aims to analyse the legal traditions to provide a framework by which he could understand the process of how Muslim jurisprudence developed.

According to Schacht's thesis, the legal hadith found in the six canonical collections emanated after the Prophet's timeby morethan 100 years. So, during this timelegislative rules were derived from the local customs enhanced by the Umayyad administrative regulations and popular practices. These practiceswerelargely based on ra'y (personal reasoning) which was later embodied by the jurists into"...tradition sfom the Companions and Successors, [to] interpret them in the light of their own 'living tradition' and allow them to be superseded by it." The contents of these traditions were the opinions and fatâwa (legal verdicts, edicts) of the Companions and the Successors. Before 150/767, some Prophetic Traditions started to be circulated by traditionists who opposed the use of ra'y.This trend was strongly opposed by the people of the ancient schools of fiqh, until it was gradually accepted by a new theory created byal-Shâfi't, which advocated theidea of the four main sources of Islamic jurisprudence. Al-Shâfi'î's position with the support of ahl al-hadith gave the Prophetic Sunnah an overriding authority over ra'y, which has no priority even over a single and isolated hadîth with a good isnâd traced back to the Prophet. So, it can be concluded that "...traditions from the Companions and Successors are earlier than those from the Prophet." Based on this conclusion, most of the legal hadith were originated during and after al-Shâfi'î's time until a large proportion of them settled in the classic collections. It was in this period and under this new fashion that different conflictinggroupsandcompetingschoolsoflawbecameawareofthenecessityofsupporting their legal views and doctrines of their schools by hadith from the Prophet in order to possess more legal power and gain more followers. To doso, they revised the materials and legal maxims acquired from the Successors and projected them to the Companions, then to the Prophet. This gives an idea of how isnâd was initially introduced into any hadithnarrationsystem.Successors'opinionsand theirargumentswere, infact, the "starting point" for the growth of legal hadith in its conventional form, isnâd and matn.

In the light of this view, Schacht's thesis followed what Goldziher had previously initiated about the origin of hadith. Their theses have advocated the theory that the largest part of hadith was created at a much later date than it was asserted by 
the early traditionists. Both believe that the significance of hadith as an authoritative guide for Muslims and an authoritative interpretation of the Qur'ân's applications had evolved over time, and during the first 90 years, at least, after the Prophet, there was only the sunnah (composed of the ancient practice of the old community) as the basis for legal codes. Those codes were not the same with the Sunnah which al-Shâfi'̂ regarded to be a synonym of hadith by his scholarly arguments. As a result, the law was first and hadith came later as justification.

However,Schachtin his analysis goes beyond his predecessors'byattempting to give an approximate date as to when the hadith initially started to appear, and when they began to be proliferated. In this direction, Schacht's unique contribution lies in advancing a practical method to date the provenance of any specific legal hadith through certain indications in matn and isnâd. He developed a technique to identify the period in which themanufacture ofanylegal hadîth is associated with. It is suggested by Schacht that the date of a hadith can be known for certain through its first appearance in legal discussion. To be clear, if there are, for example, two legal sources, one of which was older than the other, and both of them discussalegal matter, and ifonly in thelatter sourceone hadithor moreareadded sincetheyare related to thematter, then, that meansthis hadithwas (these hadith were) fabricated sometime after the writing of the earlier source.

Many examples are cited by Schacht to prove this point. For instance, he refers to al-Shâfi'î's opinion in his treatise al-Umm that there was no explicit Tradition regarding the fact that triple divorce, pronounced in one session could be counted as one divorce. However, in a later period there was a Tradition related to this matter found in Musnad of Ibn Hanbal narrated through Ibn'Abbâs stating that the triple divorce in one session was considered as"... a single divorce and is revocable."This type of conclusion by Schacht is known as an argument from silence (e silentio).

Unlike Goldziher who totally dismisses isnâd as unworthy of attention to be used for examining the historicity of the hadith, isnâd was seen by Schacht as a useful tool for dating the Traditions. According to Schacht, there is no ground to take it for granted that "...theregularpractice of using isnâds is olderthan the beginning of the secondcentury", which had then reached an apogee in the third century. These asânîd, he argues, had been attached to the Traditions in a random way, so they should be considered as fictitious. Through his isnâd-analysis method, he claims that many hadith had a few or many asânîd, and thehadith with similarorrelated contents had onetransmitterintheirasânîd, whoisconsidered to bethecommon linkandappeared somewhereinthemiddleofeach isnâd. This transmitter (the common link), Schacht argues, is the creator of the earlier part of that isnâd which went back to the Prophet, whereas the latter part was genuine.

With this analysis, he is considered to be the first critic who divided isnâd into two 
parts, genuine and invented. His objective of studying asânîd was to discover the history of the invention of any isnâd. Claiming that this situation of the common link is a frequent occurrence in hadith literature, Schacht managed to give only one example on this matter. An isnâd of a legal hadîthchosen from al-Shâfî̂'s lkhtilâf al-hadith is highlighted concerning this issue. This hadithis transmitted in Origins as in the following diagram:

Figure 3.1: Schacht's version of al-Shâfi'̂́'s isnâd of hadith

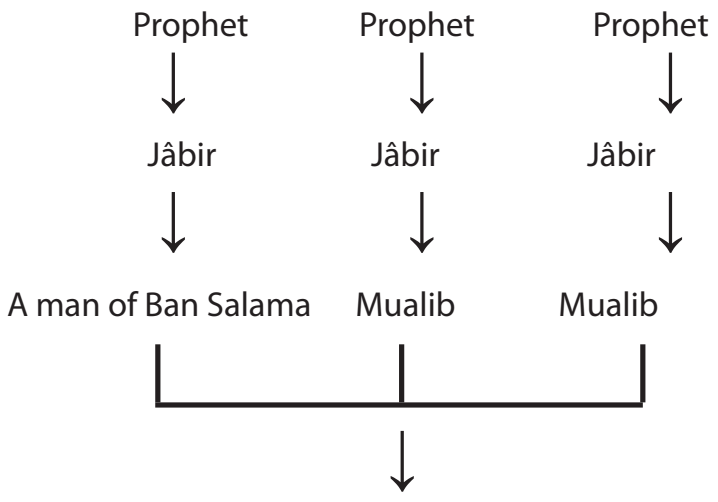

'Amr b. Abî'Amr

The freedman of $\mathrm{Mu}^{33} \mathrm{alib}$

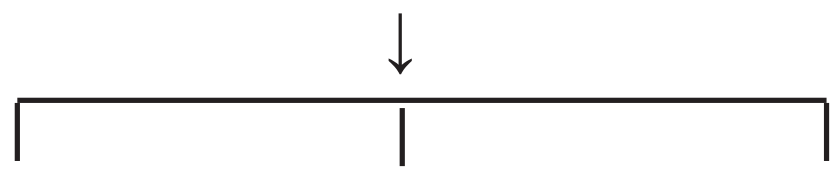

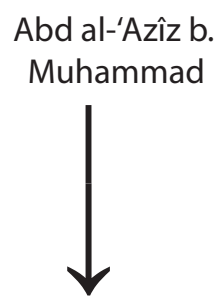

Shâfî̂
İbrahim b.

Muhammad

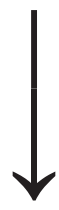

Shâfîi
Sulaymân b. Bilâl

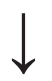

Anonymous<smiles>[CH]1CC1</smiles>

Shâfî̂

(Source: Origins, 172) 
In this diagram, as drawn by Schacht, it is 'Amr b. Abû 'Amr who is regarded by Schacht as the common link (CL) to put this report into circulation. In view of that, it shows that the $\mathrm{CL}$ belonged to the younger Successors' generation; and as a result it is a good indication of fabricating the Traditional text.'

The overall purpose that Schacht wants to achieve through his analytical approach to isnâd is to prove that the common link theory is the most adequate method that enables people to know whereand when many individual Traditions were coined. Moreover, he confidently argues that the results of using this method in conjunction with the other results of his study are not limited to juridical hadith but are also applicable to the other genres of hadith of a theological and historical nature. ${ }^{2}$

As will be discussed shortly, the theories and premises of Schacht regarding the provenance of Islamic law and the Prophetic Traditions have been, on the one hand, greatly influential. His methodology and theories, on the other, are also prone to wide criticism. One of the major criticisms of Schacht is against his claim that no genuine reports belonged to the Prophet and his Companions in the first century. This claim has been refuted by scholars such as David Powers, Noel Coulson, Fuat Sezgin, and Nabia Abbott. ${ }^{3}$ They assert that Schacht's methodology failed to distinguish between the formand contentofahadîth.Theform ofany hadîthfound in hadithliteraturewas developed after the first half of the second century/eighth century until it reached its final shape around the beginning of the third/ninth century. The original content ....may go back to an earlier time" ${ }^{4}$ perhaps even towards the middle of the first century. ${ }^{5}$

1 Nevertheless, Muhammad Azami rightlyargues that this explanation of theisnâd proposed by Schacht as a case of $C L$ transmitter is not accurate. Azami points out that there is only one chain from the Prophet to 'Amr, who transmitted it to three of his students. Then, he shows the correct version of this isnâd in conformity with al-Shâfi'î's discussion. See: M. M. Azami, Studies in Early hadith Literature: With a Critical Edition of Some Early Texts (Burr Ridge, US: American Trust Publications, 2001), 233-235. Schacht also assumes that this common link is a phenomenon observed, though not recognised by its implications, by most traditionists, then he cites al-Tirmidhî as an example. Origins, 172 . Schacht may refertowhatisknownin hadithTerminologyas Madâral-hadith (pivotofa hadithi.e.thelinkaroundwhich the chain revolves). In fact, there are significant differences between the common link meant by Schacht and the Madârused by classicscholars of hadith in their discussions. Thesedifferences arewell-explained in Halit Ozkan's paper "The Common Link and Its Relation to the Madâr," in Islamic Law and Society, 2 (2004): 42-77. Ozkan's discussion is aimed in fact to reevaluate G.H.A. Juynboll's view of the common link. Juynboll, who refined someaspects ofSchacht's theory, both share the main concept of the theory of the common link.See, G.H.A.Juynboll, MuslimTradition:Studies in Chronology, Provenanceand Authorship of Early Hadith (Cambridge: Cambridge University Press, 1983)

2 Ibid.

3 See: Powers, Studies, 1986. Also, Noel J. Coulson, A History of Islamic Law (Edinburgh: Edinburgh University Press, 1964). Fuat Sezgin, Geschichte Des Arabischen Schrifttums (History of Arabic Scholarly Writings) (Leiden: Brill, 1975) v. 2. Nabia Abbott, Studies in Arabic Literary Papyri, vol. 2.

4 Motzki, hadith, xxiv, see also S. G. Vesey-Fitzgerald, 'Nature and Resources of the Sharî'ah', in Majid Khadduriand Herbert J.Lienbesny, eds, Law in the Middle East: Origin and Development (Washington, DC: Middle East Institute, 1955), 1: 93-94.

5 See,JosefVanEss,ZwischenHaditundTheologie:StudienzumEntstehenPradestinatianischerUberlief- 
A range of particular points and conclusions in Schacht's study are also disputed by some specialists, but the most comprehensive critical workon Schacht was done by Azami who constructed some critical writings covering important aspects of the Origins. ${ }^{6}$

\subsection{The Scholarly Impact of the Studies of Goldziher and Schacht:}

As far as hadith and its historical development are concerned, the writings of the majority of non-Muslim researchers in the West have been influenced, to a large extent, by the views and theories of Goldziher and Schacht. After the appearance of MS and The Origins, theWestern scholarship of hadith became an independent subject for research. Both works are considered to be standard sources inWestern investigations of all Islamic materials. The impact they created has been felt deeply for a long period of time, and indeed their observations became the basis of any study on hadith in the West.?

Goldziher was the real founder of modern Western scholarship of Islamic studies as a whole, and his studies, especially on hadith, had an immense impact on scholars of his generation as well as his successors. For instance, Goldziher's close friendTheodore Noldeke, whowas generally recognised as the father ofWestern Qur'ânic criticism, was the first researcher to implement Goldziher's methods in MS to examine some historical reports regarding the prominent figures of early Islam. ${ }^{8}$ In a letter written to Goldziher after the second volume of MS was published, Noldeke stated that his scepticism about the originality of hadith was awakened by Goldziher. ${ }^{9}$ In his letter to Goldziher, he put it even more plainly:"Who on earth has a better understanding of hadith than you? Not even Snouck can compete with you".10 Some Orientalists such as C. H. Becker, expressed the same attitude as Noldeke in their personal letters to Goldziher while the

erung (Between HadithandTheology:Studies Concerning theTraditionson Predestination) (Berlin:De Gruyter, 1975); Gregor Schoeler, The Oral and the Written in Early Islam (Oxon, Routledge, 2006); HaraldMotzki,TheOrigins of Islamic Jurisprudence:MeccanFiqh beforetheClassicalSchools (Leiden,Brill, 2002). See also: Muhammad Hamidullah, Sahifah Hammam Ibn Munabbih by Hammam Ibn Munabbih (Luton, England: Apex Books Concern, 1979); Mu. ${ }^{3}$ afá al-Sibâî̀, Al-Sunnah wa-Makânatuhâ fî alTashrî' al-Islâmî (Beirut: al-Maktab al-Islâmî, 1976).

M. M. Azami, On Schacht's' 'Origins of Muhammadan Jurisprudence' (Cambridge: Islamic Texts Society, 1996); idem, Studies in Early Hadîth Literature.

7 Herbert, Development, 13. See also, Motzki, hadith, xxi, xxiv.

8 This is according to Noldeke's student Friedrich Zacharias Schwally in his introduction of the second edition of Geschichte des Qorans (History of the Qur'ân) second volume. Schwally was entrusted to enlarge the book for a second edition under the request of Noldeke. See, Theodor Noldeke, Târîkh al-Qur'ân (Geschichte des Qorans), translated into Arabic and published by Georges Tamer (Berlin: Konrad-Adenauer, 2004), 409-411.

9 He says in a letter sent to him: "After all I must tell you that you are a terrible man. With all your doubts about the originality of hadith you have awakened my suspicion too. Eventually, I will be more suspicious than you are!You have completely upset my simple soul."Robert Simon, IgnacGoldziher:His Life and Scholarship as Reflected in his Works and Correspondence (Leiden: Brill, 1986), 101-02. 
majority of his successors adopted his views without criticism and incorporated them in their various studies on Islam. Sometimes, they improved these views and enlarged them to be applied to other historical materials. Such scholars included Leone Caetani, Henry Lammens, David Margoliouth and Alfred Guillaume.

The same is true for Schacht, who himself was Goldizher's prominent successor, and was influencedbyhismethodologyofstudyinghadith.NodoubtthatSchachtcarriedouthishadith analysisbasedon Goldziher'sobservationsandtheoriestoestablishacriticalandinterpretive system for the study of Islam. "The theories and premises put forward by Schacht in his work werethecornerstoneswhichcouldnotbeignoredbysubsequentresearchersstudyinglslamic laworhadith. Accordingly, they have to definetheirpositionsin relation of those of Schacht. ${ }^{12}$ MostOrientalistsreactedtoOriginspositivelyandacceptedSchacht'sthesisasasolidstructure which is "... not likely to be impugned on any but a priori grounds." ${ }^{\prime \prime}$

To the majority of Western scholars, the methodological approaches of both scholars represent the introduction of critical historical approaches to materials whose meaning had become obfuscated by the dogmatic approach of the Muslim scholars. ${ }^{14}$

The studies of both Goldziher and Schacht stretched theirimpact to an unexpected end; the Muslim world. Since the dawn of modernity, the sceptical conclusions drawn by Orientalists about the reliability of hadith had posed epistemological and theological challenges to many Muslims. This trend generated various responses from Muslim scholars. Those responses ranged from total acceptance of the Western criticism of hadith to a total rejection of it.

Among the majority of Muslims scholars, the style of hadith study represented in the works of Goldziher and Schacht has generated either ridicule or suspicion. They have regarded the scepticism of both scholars concerning hadith materials as a result of ignorance, or as an expression of'Orientalism' manifested in a desire to prove that documentations for much of Islamic belief is forged..$^{15}$ Others, nevertheless, have been influenced bysuchargumentsandhaveembracedthewholescepticalviewsregardingtheorigins of hadith.

For instance, in nineteenth-century India, Muslims encountered, for the first time, powerfulargumentsquestioning the integrity of allTraditions in a systematic and logical way. The arguments and questions were brought to the awareness of Muslims through the intellectual activities of Christian missionaries and some European polemicists who tried to show the "irrationality" of Islam by presenting what they thought were some 
problematicissuesandcontradictoryelementsfoundinhadith.Someoftheseissueswere the nature of the jinn as represented in the hadith texts as other beings who inhabit the earth with humans, and also the hadîthof the Fly. ${ }^{16}$ Some Muslim thinkers, especially those who had close contact with those people in India, reacted intellectually to the arguments in defence of Islam. The reaction was unprecedented in Muslim history in its kind of response. The cost was that the entireSunnah as alegal sharîah proof was denied.

Theystruggled tofindappropriateanswersforeachargument; however, theyfound themselves at last convinced by theWestern arguments. So, some Indian figures including Sir Sayed Ahmad Khan, Chiragh 'Alî, and Khawaja Ahmad Armistari turned to the Qur'ân to solve the dilemma and proclaimed that only the Qur'ân could be entirely trusted as a perfect source of Islam which has to be followed exclusively. They treated the Sunnah literature as an untrue representation of the Prophet's life and message that is full of paradoxes. These ideas against the hadith then spread widely among Indian Muslims, and attracted a number of followers. One of them was Mistri Ramadan whoattacked the criticism of early Muslim hadith as a pointless methodologybecause, according to him, all asânîd were forged so that the methodology could not be used to verify the Traditions. ${ }^{17}$ One of the goals set by this movement was to abandon the use of hadith literature in deriving legal laws and rely only on the Qur'ân. Armistari, for instance, authored a book on the Qur'ân to show how the laws pertaining to the Islamic law of inheritance, for example, could be extracted from the Qur'ân alone. ${ }^{18}$

The arguments of those who reject hadith became the foundation of a later movement called "al-Qur'ânîyn/Qur'anists". In modern times, the new 'Qur'anists' in different parts of the world carry out the same mission and views maintained by their forefathers. One of the basic current works that supports this argument is authored by the Malaysian researcher, Kassim Ahmad, entitled 'hadith: A Re-evaluation'. ${ }^{19}$ In this

16 The hadithreads: "If a fly falls into one of your containers [of food or drink], immerse it completely before removing it, for under one of its wings there is venom and under another there is (its) antidote". Sahîh al-Bukhârî, 4: 123. There was a heated debate over the content of this hadithespecially by the Qur'ânîyn who saw it as irrational and against modern medical science so it could not be possible to be the words of the Prophet. Surprisingly, there are recent scientific researches whose results seem to support this narration. See for example: Dharne, M.S. et al. "Antibacterial activities of multi drug resistant Myroides odoratimimus bacteria isolated from adult flesh flies (Diptera: Sarcophagidae) are independent of metallo beta-lactamase gene," Braz. J. Microbiol., 39 (2008): 397-404. See the online versionofthisarticleat:http://www.scielo.br/scielo.php?script=sci_arttext\&pid=\$15178382200800020 0035\&lng=en\&nrm=iso Also see, O. Lung, L. Kuo and M.F. Wolfner. Drosophila males transfer antibacterial proteinsfrom theiraccessoryglandandejaculatoryducttotheirmates, Journalof InsectPhysiology, 47 (2001):617-622. Also, an article entitled The new buzz on antibiotics was published online in http://abc.gov.au/science/articles/2002/10/01/689400.htm.

17 Daniel W. Brown, Rethinking Tradition in Modern Islamic Thought (Cambridge: Cambridge University Press, 1999), 98. Ibid., 46-47. Kassim Ahmad: hadith: A Reevaluation (Kuala Lumpur: Media Indah, 1986), 8-9. This book was ban- 
work, the critical remarks made by influential Western researchers who criticised and questioned theauthenticity ofhadithanditslegalstatuswereclearlyembraced toshore up the original theme of the book which was dedicated entirely to rejecting hadith and only accepting the Qur'ân as a sacred source. The evolution of Qur'anist ideas about the Traditions and their religious status as Daniel Brown identifies, was affected by Orientalistideologies mainly created by Goldziherand Schacht, which werealso recruited as polemical missionary literature..$^{20} \mathrm{It} \mathrm{is} \mathrm{obvious} \mathrm{that} \mathrm{the} \mathrm{foundation} \mathrm{of} \mathrm{this} \mathrm{movement}$ could be traced to the criticism and scrutiny by Western scholars of Islam which later influenced some Muslim scholars who believed that hadith, unlike the Qur'ân, could not stand up to criticism. ${ }^{21}$ Thus, it made them look back on the hadith to examine its basis and origins in Islam.

The anti-hadith trend was not only prevalent in India; it found its way to impact on other terrain in the Arab world, namely; Egypt. In the early $19^{\text {th }}$-century, some Arab intellectualsormodernistsbegantoespousesomeoftheargumentsofGoldziherandthose of the Orientalists whowereinfluenced byhim. Goldziher's views werefirstintroduced to Arab Muslims through the translation of an English digest for the work of Goldziher published by a Christian missionary, and then published in Arabic in an obscure missionary journal in Egypt called "al-Shraq wa al-Gharb".22 This was not the only channel of how Western critical studies of hadith came to Egypt. It was also through students (an example will be given shortly) who were sent to study in Europe. One of the important early $19^{\text {th }}$-century Arab modernists was $A^{-}$mad Amîn who discussed some issues related to hadith transmission and documentation in his popular book "Fajr al-Islâm".23 During the discussionscontainedinthebook, hesupported hisclaims by referring toGoldziher'sopinionsonthehistoricaldevelopmentofhadith. However, heusuallyexpressedGoldziher's thoughts as his own without mentioning the source of those views. ${ }^{24}$

Therearealso somescholarswhoopenlychallenged theorthodoxviews of Muslims about the position of hadith, and admired the works done by Orientalists in this regard. In 1939, 'Alî 'Abd al-Qâdir, who obtained his doctoral degree from Germany, was appointed as a teacher in al-Azhar University on the subject of Islamic legislation and

ned by the Malaysian Home Ministry on 8 July 1986.

Brown, Rethinking, 34.

lbid., 43-44.

Al-Siddîq Bashîr Na·r, Al-Ta'lîqât al-Naqdîyah’alá Kitâb Dirasât Muhammadîyah (London: Markaz al'alam al-Islâmî li-Dirâsat al-Istishrâq, 2008), 72-74.

Ahmad Amîn, Fajr al-Islâm (Cairo: Maktabat al-Nahdah al-Misrîyah, 1965). He wrote two sections in chapter six related to hadith and its documentation, and its relation to Islamic legislation.

According to Mahmud Shâkir, it was a common practice of Arab modernists during that era such as Tâhâ Husayn, Ahmad Amîn, to plagiarise the Orientalists' opinions such as, those of Goldziher and Margoliouth, on many occasions without giving any credit to them. See, Mahmud Muhammad Shâkir, Al-Mutanabbî (Cairo: Matba'at al-Madanî, 1978) 156-167. 
history. According to some of his students, he declared that after 14 years of studying in al-Azhar he had not gained a true understanding of Islam, but only attained this after studying in Germany. ${ }^{25}$ While teaching his students, he used to quote from the MS and use Goldziher's views as established facts. ${ }^{26}$

In the same period of time, there was an influential thinker named $\mathrm{Ma}^{-} \mathrm{md} \mathrm{Ab}$ Rayyah whose focus on hadith criticism was aimed at disproving the validity and authenticity of the major content of hadith compilations. For this purpose, he wrotea monographentitled Adwâ' 'aláal-Sunnahal-Muhammadîyah. Heonly kept themutawâtir (recurrent) hadith, which existed in small quantities, as valuable, while the rest were judged as mereforgeries. ${ }^{27}$ Generally, his arguments reflected more or less the Orientalist views especially those of Aloys Sprenger, Von Kremer, and Goldziher. Most of the sources he consulted in his work were used by Goldziher in MS.

In comparison with the Qur'anist movement in India, Arab modernists did not hold the'Qur'ân-only'position in their arguments, and if they did, they did it implicitly. Nevertheless, most of their early arguments were not in favour of total rejection of the entire Sunnah literature. On the contrary, they could accept hadith if they matched the criteria set by them for the acceptance of any hadith. They argue that if any haditthwas classifiedas mutawâtir, or not contradictory to the Qur'ân, orcompatible to modern reason, it would be worthy of consideration, otherwise it must have been fabricated. ${ }^{28}$ In the last few decades, the notion of' Qur'ân-only'in the Muslim world has become prevalentamongthosewhoembracedtheanti-hadiththoughts ofthepreviousmodernists mentionedabove. Thismightbeprimarilybased on theQur'anistmovementwhich has becomemoremethodologicaland systematicsincethemovementofTolu-e-Islam(Resurgence of Islam) led by Ghulam Ahmed Parvez (1903-1985) ${ }^{22}$, and the establishment

25 One of his students was the renowned scholar Musthafá al-Sibâî. See his account on this point in his book, Al-Istishrâq wa-al-Mustashriqn: Mâ la-hum wa-mâ'Alayhim, 2 2nd ed. (Beirut:al-Maktab al-Islâmî, 1979), 8-13.

26

$$
\text { kistan }
$$
doctrine of the sufficiency of the Qur'ân. Heemphasized the notion that the Prophet's mission was solely to transmit the revealed text to him, and his Sunnah was intended to be valid for his time only. In 1938, Parvez became the leading voice of Ahl Al-Qur'ân especially when he establishedajournal which was named after his movement Tolu-e-Islam. Moreover, he founded a country-wide network for spreading his ideas of the Qur'ânicteachingscalledBazm-e-Tolu-e-Islam. Around40bookswerewritten by Parvezonvarioustopics of the Qur'ân. Such books include'Mafhum-ul-Qur'ân' (Exposition of the Holy Qur'ân) in 8 volumes, 'Lugh'atul-Qur'ân' (Dictionary of the words and Concepts of the Qur'ân) in 4 volumes, and 'Niz'am-e-Rabubiyyat' (Qur'ânic Economic Order). In these publications, he produced a number of sophisticated arguments agat inst Ahl al-hadith supporting his own views. For more details see: Brown, Rethinking Tradition, 45, 54-57, 90-91, 100. See also, http://www.tolueislam.com/index.htm (accessed May 06, 2010). 
of United Submitters International (USI) founded by Rashad Khalifa (1935-1990) in the United States of America. ${ }^{30}$

From the discourse of the Qur'anists and modernists, it is understandable that their move against the role of the Sunnah in Islamic thought was an attempt to go beyond the sanctifying look at the Islamic heritage and intend to re-consider the postulates rooted in the religious conscience concerning the Prophetic Traditions. This critical position on hadith was basically, as stated by Muhammad Hamzah, the fruit of two factors. First, it was the study of other opinions of Mu'tazilîand Shî'î intellectual argumentsonhadithwhichchallenged themainstreamdogma. Second, itwastheeffects ofstudyingtheOrientalistopinionsandtheirmethods of criticism, whichconsequently led some modern Muslim thinkers to question the legal and religious status of the role of the Sunnah in Muslim thought. ${ }^{31}$

The new school of thought led by modernists and Qur'anists was, and still is, rejected bymainstream religiousschoolswhosescholars seethis modernintellectualattack on the Sunnah and its role in Islam as a result of the pressure of modernity and Western civilisation, and is not based on sound scholarship. Most of those opponents belong to traditionalists or salafî scholarly groups. In the traditionalist view, the attitude of modernthoughtconcerninghadithwasformedinaccordancewithWesterncriticismof hadith. So, titles like"mustaghribn" "Occidentalists" and "imitators of the Orientalists" were frequently repeated in traditionalist discourse describing the modernists when discussing their anti-hadith views. . $^{32}$ For the salafîscholars, the real revival and prosperity of the Muslim ummah (community of Muslims worldwide) is in adherence to the Prophetic Sunnah with sincere implementation of its teachings in one's life.

In the midst of these debates, a moderate approach to the subject was offered to reconsolidate the two parties. The leading figure of this trend was the Pakistani scholar

30 The main specific beliefs of the United Submitters International (USI) group are the dedication of all worship practices to Allah alone, upholding the Qur'an alone, and rejecting the traditional hadith as fabrications and lies attributed to Prophet Muhammad by hisenemies. Thefounder Rashad Khalifa was murdered in 1990 in Tucson, USA in suspicious circumstances. For more information on their critical evaluation of hadith see, http://submission.org/hadith/hadith2.html (accessed February 13, 2010).

Muhammad Hamzah, al-hadith al-Nabawî, 346-347.

See, for example, the introduction of Mudammad Nâsir al-Dîn al-Albânî in his, Mukhtaar Sahîh alImâmal-Bukhârî, to suchscholars, adherencetotheSunnahandaffirming theirconfidenceintheclassic hadith collections means also relying on the Muslim critical approaches of authenticating the Traditions. The late Egyptian scholar Muhammad al-Ghazâlî (1917-1996) says there is no equivalence in the history of human culture in terms of establishing a set of principles of verification resembling those of the early traditionists. Al-Ghazâlî, Al-Sunnah al-Nabawîyah, 13 $3^{\text {th }}$ ed. (Cairo: Dâr al-Shurq, 2005), 19. However, to them this does not mean this confidence in the principles of verification will stop them from carrying out the same critical practice to classic hadith compilations. They believe that criticism of hadith did not end by the fourth century A.H., and was consigned to books. Al-Albânî asserts that "...religious knowledge cannot fall into rigidity". Al-Albânî, Sahîh al-Targhîb wa-al-Tarhîb, 1: 4. 
Fazlul Rahman Malak. ${ }^{33}$ In principle, Rahman agreed with the general conclusions of Goldziher and Schacht. After summarising Goldziher's scientific study of hadith, he states that the Traditions "...must be regarded as being on the whole unreliable as a source of the Prophet's own teaching and conduct." ${ }^{34}$ Regarding Schacht, Rahman admired his extensive and systematic comparison of legal Traditions and praised it as indisputable and methodically sound..$^{35} \mathrm{He}$ supported Schacht's observation that the concept of the Sunnah of the Prophet was not part of the first century, and that it was al-Shâfi'îwho first introduced this conceptaround two centuries after the Prophet's death. Nevertheless, he believed that Schacht's observation was not completely correct, because, according to Rahman, he failed to differentiate between the content of the Sunnah and the concept of the Sunnah. The content is the normative exemplaryaction of the Prophet, whereas the concept is its interpretation, the actual'silent' practice of the community. In Rahman's view, the Prophet was not a pan-legist but a religious reformer. His actions and sayings could not cater for the needs of the ever-expanding Muslim empire. Therefore, his Sunnah was interpreted according to the demands of the time, and it was called the Sunnah because its roots were taken from the apostolic model. This was, to Rahman, a form of high intellectual creativity that the early generations of Muslims exercised through ijtihâd ${ }^{36}$ (intellectual reasoning to understand laws), and because of that the hadith collections, at least, is believed to breathe the spirit of the Prophet and maintain religious values. ${ }^{37}$ Due to this fact, Rahman seemed to be utterly convinced that no part of the hadith literature should be discarded outright.

From the discussion above it is obvious that the critical studies conducted by Goldziher and Schacht, which influenced theirfellow Orientalists, had a strong impact on the Muslim world too, where many thinkers not only echoed the Orientalist sceptical views on hadith butalsocreatedanewmovementcallingforanewapproachtolslambasedonthepremises of "the Qur'ân-only" ideology. The true impact of Orientalist works on the Muslims was throughtheintroduction of modern historical research methods to Muslim thought, and it had a tremendousimpacton modernist Muslim minds. It is also a fact that the modern attitudetohadithbenefitedfromthenon-SunniviewswhichwereintroducedthroughOrientalist works as logical tools of argument against theTraditions. The common denominator of those recentgroups ofMuslimsmentioned aboveand their counterparts in theWest is that all of them are directly or indirectly indebted, in varying degrees, to the scholarly premises on the origins of hadith literature formulated by Goldziher and Schacht.

33 Famously known as Fazlur Rahman.

34 Fazlur Rahman, Islamic Methodology in History (Karachi: Central Institute of Islamic Research, 1965), 44.

35 Ibid., 47-48.

36 SeeWael B. Hallaq, "Was the Gate of ljtihâd Closed?", International Journal of Middle Eastern Studies, 16 (1984): 3-4.

37 Rahman, Islamic Methodology, 44-45. 
Western Works and Views On Hadith: Begınnıngs, Nature, and Impact

\subsection{Conclusion}

It has becomeclearfrom the discussion in thisstudy that since 1890, the role of hadith has grasped the attention of Orientalists who sought to identify the origins of Islam and its legal and religious institutions. The question of authenticity and authority was at the heart of their investigations. Until the end of the first half of the $20^{\text {th }}$ century, two major leading scholars; namely Goldziher and Schacht, were the only prominent figures who successfully attempted to answer this question by subjecting the Traditions to historical criticism which were very much inspired by the development in critical-textual studies and source-criticism methods witnessed during the $19^{\text {th }}$ century. The investigations of both scholars conclude that the contents of hadith contain evidence of much later periods, and the majority of Traditions were falsely attributed to the Prophet. By this conclusion, theymethodologicallyadvocatedascepticalattitudetowardtheentirehadith literature. Significantly, the review of the works of both scholars reveal that Goldziher, on theonehand,makesgeneralobservationsanddoesnotpresentanymethodologicaltools to work with, while Schacht, on the other hand, is more technical and sophisticated in his arguments. Regardless of the views of their opponents, Goldziher and Schacht had a profound impact, not only on theWest, but also on the East where heated debates arose in response to the question of the authenticity of the whole corpus of hadith.

\section{References}

Ahmad Von Denffer in Literature on Hadith in European languages: A Bbibliography (Leicester: Islamic Foundation, 1981)

Aharon Layish, "Notes on Joseph Schacht's Contribution to the Study of Islamic Law," British Society for Middle Eastern Studies, 9, (1982)

Akram 'iy«' al-'Umar» in Mawqif al-Istishr«q min al-S»rah wa-al-Sunnah al-Nabaw»yah (Riyadh: D«r Ishb»|»y«, 1997), 33-35.

Aloys Sprenger: 'On the Origin and Progress of Writing down Historical Facts among the Musulmans', Journal of the Asiatic Society of Bengal, 25 (1856)

Andrew Rippin, "Western Scholarship and the Qur'«n," in The Cambridge Companion to the Qur'«n, ed. Jane Barthelemy de Herbelot: Bibliotheque Orientale: ou Dictionnaire universel (Paris: par la Compagnie des Libraires, 1697)

Bilal Sambur, "The Insider/Outsider Problem in the Study of Islam”, Islamic Quarterly, 46 (2002) Bernard Lewis, "Obituary: Joseph Schacht," Bulletin of the School of Oriental and African Studies, 33 (1970)

Buchhandlung, 1843). Mohammad Khalifa, The Sublime Qur'«n and Orientalsim (London: Longman Group, 1982)

Coulson. N. J. Coulson, A History of Islamic Law (Edinburgh: Edinburgh University Press, 1964).

David S. Powers, Studies in Qur'an and hadith:The Formation of the Law of Inheritance (Berkeley, CA: University of California Press, 1986)

D. S. Margoliouth, "On Moslem Traditon", The Muslim World, 2 (1912).

Dammen McAuliffe, (Cambridge: Cambridge University Press, 2006) 
Edgar Krentz, The Historical-Critical Method (Oregon: Wipf and Stock Publishers, 2002).

Fazlur Rahman, Islamic Methodology in History (Karachi: Central Institute of Islamic Research, 1965)

Fuat Sezgin, Geschichte Des Arabischen Schrifttums (History of Arabic Scholarly Writings) (Leiden: Brill, 1975)

Gregor Schoeler, The Oral and the Written in Early Islam (Oxon, Routledge, 2006)

Gustav Weil, Mohammed der Prophet, sein Leben und seine Lehre (Stuttgart: Verlag der J.

B. Metzler'schen H. Ritter, "Review of the Origins of Muhammadan Jurisprudence, by Joseph Schacht," Oriens 4 (1951).

H. A. R. Gibb, "Review of the Origins of Muhammadan Jurisprudence by Joseph

Schacht", Journal of Comparative Legislation and International Law, 33 (1951).

Herbert Berg, The Development of Exegesis in Early Islam, The Authenticity of Muslim

Literature from the Formative Period, (Great Britain, 2000)

Henry Lammens, Islam Beliefs and Institutions, trans. Denison Ross (London: Methuen

Co. \& Ltd., 1929).

M. Mohar, Orientalist Studies and the Qur'«n, A Historical Survey (Medina: Mujamma' al-Malik Fahad, 2006).

Harald Motzki, The Origins of the Islamic Jurisprudence: Meccan Fiqh before the Classical Schools (Leiden, Brill, 2002)

I. Goldziher, Mythology among the Hebrews and Its Historical Development, (London:

Longmans Green 1877)

Johann Fueck, "The Role of Traditionalism in Islam", in had»th: Origins and Developments, ed. Harald J. N. D. Anderson, "Review of the Origins of Muhammadan Jurisprudence, by Joseph Schacht", Die Welt des Islams 2 (1952).

Muhammad Zubayr Siddiqi, Had»th Literature: Its Origin, Development and Special

Features (Cambridge: The Islamic Texts Society, 2008

Muhammad Hamidullah, Sahifah Hammam Ibn Munabbih by Hammam Ibn Munabbih

(Luton, England: Apex Books Concern, 1979)

Nabia Abbott, Studies in Arabic Literary Papyri: Quranic Commentary and Tradition

(Chicago: University of Chicago Press, 1967)

Noel J. Coulson, A History of Islamic Law (Edinburgh: Edinburgh University Press, 1964). Majid Khadduri and Herbert J. Lienbesny, eds, Law in the Middle East: Origin and Development (Washington, DC: Middle East Institute, 1955)

Theodor Noldeke, T«r»kh al-Qur'«n (Geschichte des Qorans), translated into Arabic and published by Georges Tamer (Berlin: Konrad-Adenauer, 2004)

Van Austin Harvey, The Historian and the Believer: The Morality of Historical Knowledge and Christian Belief (New York: University of Illinois Press, 1996)

Wael B. Hallaq, "Was the Gate of ljtih«d Closed?", International Journal of Middle Eastern Studies, 16 (1984)

"The Authenticity of Prophetic hadıth: A Pseudo-problem,"Studia Islamica, 89 (1999)

Ze'ev Maghen, "Dead Tradition: Joseph Schacht and the Origins of "Popular Practice','

Islamic Law and Society, 10 (2003). 